\title{
Cultivar Differences and the Effect of Winter Temperature on Flower Bud Development in Blackberry
}

\author{
Fumiomi Takeda ${ }^{1}$ \\ U.S. Department of Agriculture, Agricultural Research Service, Appalachian Fruit Research Station, 45 \\ Wiltshire Road, Kearneysville, WV 25430 \\ Bernadine C. Strik ${ }^{2}$ and Derek Peacock ${ }^{3}$ \\ Department of Horticulture, 4017 Agriculture and Life Sciences Building, Oregon State University, \\ Corvallis, OR 97331 \\ John R. Clark ${ }^{2}$ \\ Department of Horticulture, 316 Plant Science Building, University of Arkansas, Fayetteville, AR 72701
}

\begin{abstract}
AdDitional INDEX wORDs. Rubus, differentiation, floral primordia, floricanes, inflorescence, microscopy
Abstract. Transition to reproductive development and subsequent development of floral primordia (e.g., sepals, petals, stamens, and pistils) were determined in several blackberry (Rubus subgenus Rubus Watson) cultivars (Boysen, Cherokee, Chester Thornless, Marion, and Thornless Evergreen) growing in one or more locations (Clarksville, Ark., Aurora and Hillsboro, Ore., and Kearneysville, W. Va.). Also, daily maximum, mean, and minimum temperatures were recorded at three sites (Clarksville, Aurora, and Kearneysville) for the September to April sampling period. In buds of 'Boysen' and 'Marion' from Oregon, sepal primordia were first observed in November and December, respectively. Further floral bud development continued into January. Sepal development in 'Cherokee' buds occurred in October in Oregon and in December in Arkansas. At all three sites, the buds of 'Chester Thornless' blackberry remained undifferentiated until spring. The average mean temperatures in Oregon were generally well above $5{ }^{\circ} \mathrm{C}$ during the bud sampling period, but were near $0^{\circ} \mathrm{C}$ on most days from mid-December to January in Arkansas and from December to late-February in West Virginia. The phenology of flower bud differentiation varied among the cultivars and was strongly influenced by prevailing winter temperatures. The results suggest that the shortening day lengths of late summer trigger flower bud development in blackberry. Floral bud development in blackberry, once initiated, was continuous; however, periods of low temperature $\left(<2{ }^{\circ} \mathrm{C}\right)$ can arrest development.
\end{abstract}

Blackberry (Rubus subgenus Rubus Watson) cultivars of North America originated from the interbreeding of many genetically heterogeneous and morphologically variable species (Moore and Skirvin, 1990). Cultivars differ greatly in fruit and plant growth habit. Based on gross morphology, they are classified as erect thorny, erect thornless, western trailing, and semi-erect eastern thornless (Crandall, 1995). While some blackberries are well adapted to a specific region of the United States, others have become commercially important in several, distinct climatic and geographic regions. The western trailing blackberries (e.g., 'Boysen', 'Marion', and 'Thornless Evergreen') are grown mainly in Oregon. In contrast, semierect thornless 'Chester Thornless' blackberry released by the U.S. Department of Agriculture (USDA), and erect, thorny 'Cherokee' blackberry from the University of Arkansas can be grown throughout the temperate zone from the southern Atlantic coast region to California and Oregon on the Pacific coast. Weather, specifically low winter temperatures, limits where blackberries can be grown (Crandall, 1995). In

Received for publication 10 Oct. 2001. Accepted for publication 5 Apr. 2002. We acknowledge the assistance of Ann K. Hummell, Wilbur Hershberger, and Timothy Artlip, all with the USDA in W. Va., for statistical analysis and graphic work. Kenda Woodburn and Dan Chapman in Arkansas and Gloria Murray in Oregon provided assistance in material handling. Thanks to Thomas Tworkoski and James Carew for critical review of this manuscript.

${ }^{1}$ Research horticulturist and corresponding author; e-mail ftakeda@ afrs.ars.usda.gov.

${ }^{2}$ Professor.

${ }^{3}$ Research assistant. Current address R\&D Dept., Enfield Farms Inc., Lynden, WA 98264. general, erect blackberries can survive much lower winter temperatures (less than $-15{ }^{\circ} \mathrm{C}$ ) than trailing types, and thorny cultivars are more winter hardy than thornless types (Warmund and George, 1990)

Phenology and biology of flowering in both cultivated and wild raspberries and blackberries have been studied under diverse environmental conditions in Scotland (Robertson, 1957), and in the United States in Maryland (Waldo, 1933), Missouri (Warmund and George, 1990), Oregon (Waldo, 1933), and West Virginia (Takeda and Wisniewski, 1989). Recently, Carew et al. (2000) provided a review on how the growth cycles of biennial and primocane-fruiting raspberries are controlled by the environment, the genotype and cultural practices. Under temperate-zone growing conditions, biennial-fruiting brambles have a clearly defined seasonal pattern of dormancy, entering the endodormant phase as a result of shortened photoperiod and low and moderate temperatures in autumn, and exiting after sufficient winter chilling (Moore and Caldwell, 1985). In the red raspberry (R. idaeus L.), cultivars Latham, Autumn Bliss, and Glen Cova were reported to reach maximum dormancy in October and be gradually released from dormancy until January, after which time growth could resume under long photoperiod and high temperatures (Brierley, 1948; Carew et al., 2001). Low temperatures can also have vernalizing effects on floral bud development (Metzger, 1996). Flowering can be promoted by a cold treatment (Thomas and Vince-Prue, 1997). However, vernalization does not induce floral initiation; it creates the capacity for subsequent flower bud break (Chouard, 1960). 
Blackberries are different from red raspberries in both the time when dormancy begins and in the intensity of dormancy attained (Jennings, 1988). Blackberries grow well into the autumn and the canes do not form a conspicuous terminal rosette of leaves. Cane growth is likely to be stopped by either decreasing temperatures or rooting at the tips if the canes are in contact with the soil. From the assessment of freezing injury prior to and after maximum rest intensity had been achieved in blackberries, Warmund et al. (1989) reported that the endodormant phase in blackberries appears to be completed in January, after which growth could be induced with high temperatures. However, the physiological relationship between endodormancy and reproductive bud development is not well understood since the initiation of flower buds can occur prior to the endodormant phase and bud development may continue throughout the rest period with an increasing complexity in the floral organs within a dormant bud of some cultivars but not in others (Takeda and Wisniewski, 1989).

Generally, short days and low temperatures cause flower bud initiation in brambles (Williams, 1959). Floral initiation in 'Austin Thornless' dewberry and wild, trailing blackberries in Maryland occurred as early as September and in spring in 'Darrow', 'Ashton Cross', and 'Himalaya Giant' blackberries in Missouri and Oregon (Waldo, 1933; Warmund et al., 1988). Takeda and Wisniewski (1989) and Warmund et al. (1992) reported that in West Virginia, the time of flower bud initiation for 'Black Satin' was in the fall, but was in the spring for 'Hull Thornless'. The time of flower initiation can vary significantly from site to site. The primocane-fruiting 'Lloyd George' raspberry initiated flowers in July in Nottingham, U.K. (Williams, 1959), but not until late August in Dundee, U.K. (Robertson, 1957). Hoover et al. (1989) reported that when primocane-fruiting raspberry cultivars were grown at a range of sites across North America, temperature emerged as the critical factor for cane growth as it was correlated with heat unit accumulation (base $5{ }^{\circ} \mathrm{C}$ ) throughout the season. However, the difference in harvest dates recorded at five locations could not be explained by differences in accumulation of heat units.

Little is known about the flower bud development in cultivars of commercial importance in Oregon. The onset, progression, and completion of reproductive development appear to be highly variable among blackberry cultivars and apparently influenced, in part, by prevailing environmental (e.g., temperature) and some internal factors. Also, studies detailing the progression of flower bud development in blackberries in association with prevailing winter temperatures at several locations have not been presented.

Differentiation of flower buds in many deciduous fruit and nut trees takes place during the summer or early fall preceding the spring in which the buds open and set fruit. In most of these species under a temperate-zone or Mediterranean climatic conditions, once differentiation has been initiated there is continuous development of floral organs until bloom the following spring (Buban and Faust, 1982; Tufts and Morrow, 1925). However, in pistillate flowers of persian walnut (Juglans regia L.) (Lin et al., 1977) and pistachio (Pistacia vera L.) (Takeda et al., 1979), floral initiation occurred in early summer, but the development of the components of flowers was shown not to be continuous, as there were periods of 3 to 9 months in which little or no growth and development took place. The reason for discontinuous floral development in these species is not known, but it may be associated with the incomplete complement of floral parts (Takeda et al., 1979).

The objectives of this study were to determine 1) the time of transition to reproductive development and the subsequent development of floral primordia in several blackberry cultivars growing at one or more sites and 2) the relationship between the rate of floral bud development and winter temperatures.

\section{Materials and Methods}

Axillary bud samples were collected at four sites [University of Arkansas Fruit Substation, Clarksville, Ark.; Oregon State University, North Willamette Research and Extension Center (NWREC), Aurora, Ore.; a grower field in Hillsboro, Ore. (35 km from NWREC); and USDA Appalachian Fruit Research Station (AFRS), Kearneysville, W.Va.] at 3- to 4-week intervals from September to April during the 1995-96 and 1996-97 growing seasons and at 2- to 3-week intervals from August to October 2001. Cultivars and their collection sites were as follows: trailing 'Boysen', 'Marion', and 'Thornless Evergreen' blackberries from NWREC, Oregon; erect 'Cherokee' blackberry from Arkansas and from a commercial plantation in Hillsboro, and semi-erect 'Chester Thornless' blackberry from Arkansas, NWREC, and AFRS. Axillary buds were excised from canes, killed in a fixative, stored in $70 \%$ ethanol, dissected, and examined under a stereoscope. The degree of differentiation of the terminal floral bud, based on a numerical rating system of 1 to 10 (Takeda and Wisniewski, 1989), was used to quantify the developmental stages of each bud. For confirmation, a limited number of fixed buds were dehydrated, critical-point-dried with $\mathrm{CO}_{2}$, sputtercoated with gold-palladium alloy, and examined on a scanning electron microscope (StereoScan model 120; Cambridge Instruments Ltd., Cambridge, U.K.).

At Clarksville, six lateral branches, trimmed to $50-\mathrm{cm}$ lengths, on 1.0 to 1.3 -m high floricanes were harvested from 15-year-old (in 1995) 'Cherokee' and 3-year-old 'Chester Thornless' blackberry plants that were growing in rows set $3.7 \mathrm{~m}$. The rows were established with transplants planted $0.6 \mathrm{~m}$ apart. In subsequent years, the 'Cherokee' rows were maintained as a 0.6-m-wide hedgerow while the 'Chester Thornless' rows were maintained in a hill system (Patterson, 1992). The soil was a Linker fine sandy loam soil (Typic Hapludults). Standard bramble production practices for the midsouthern U.S., such as annual applications of $\mathrm{N}-$ $\mathrm{P}-\mathrm{K}\left(50,21.7,41.5 \mathrm{~kg} \cdot \mathrm{ha}^{-1}\right.$, respectively), chemical weed control, spring application of liquid lime sulfur for anthracnose control, summer topping of primocanes, dormant-season removal of floricanes, and overhead sprinkler irrigation on an as needed basis in the summer (Patterson, 1992).

In Oregon, a sample of 10 to 20 axillary buds from main and lateral branches in the middle portion of three floricanes of 'Boysen', 'Marion', and 'Thornless Evergreen' blackberry plants were processed on each collection date. These trailing blackberry cultivars were 9 years old (in 1995) and were grown in the alternate-year production system at a $2.4 \times 3 \mathrm{~m}$ spacing for 'Marion' and 'Thornless Evergreen' and a $1.8 \times 3 \mathrm{~m}$ spacing for 'Boysen' at NWREC. Plants were sampled following an off year of only primocane growth (Strik, 1992). 'Chester Thornless' blackberry plants used in this study at NWREC were 9 years old (in 1995), spaced at $1.5 \times 3 \mathrm{~m}$, and were trained to a two-wire $\mathrm{T}$ trellis, $2 \mathrm{~m}$ high. Lateral branches located at 1 to $2 \mathrm{~m}$ high were collected throughout the sampling period. 'Cherokee' blackberry bud samples were collected from a 6-year-old (in 1995) grower field located in Hillsboro. Plants were spaced at $0.9 \times 3 \mathrm{~m}$ and were trained to a temporary $\mathrm{T}$ trellis (cross-arm at $\approx 1 \mathrm{~m} \mathrm{high}$ ). Lateral branches were dormant-pruned by machine to form a 


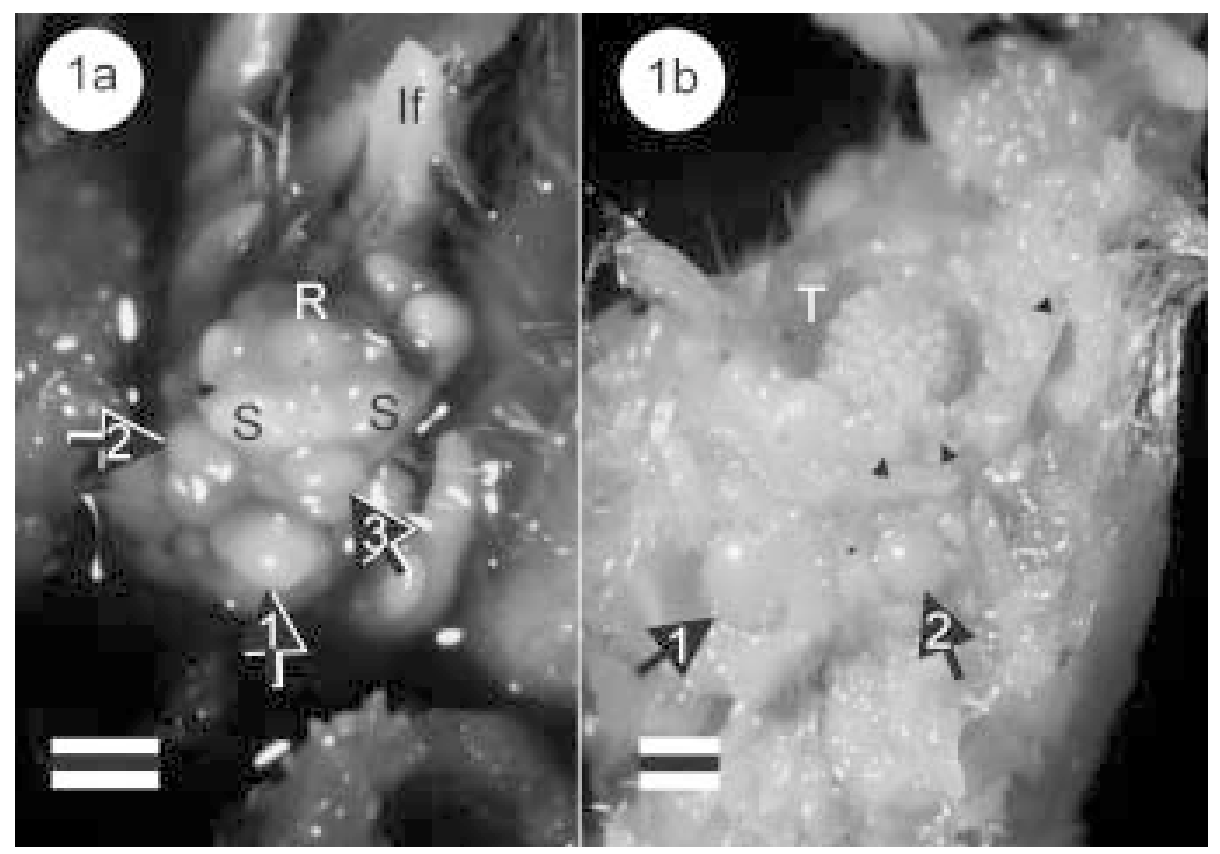

Meteorological data were collected daily at Clarksville (lat. $35^{\circ} 2^{\prime} \mathrm{N}$ ), Aurora (lat. $45^{\circ}$ $15^{\prime} \mathrm{N}$ ), and Kearneysville (lat. $39^{\circ} 25^{\prime} \mathrm{N}$ ). For each location, monthly average maximum and minimum temperatures were calculated for the period from September to April during 1995-96 and 1996-97.

All morphological and developmental data were analyzed by analysis of variance (ANOVA). Location differences were compared using mean separation by LSD or Duncan's multiple range test $(P \leq 0.05)$, with the PROC GLM function of SAS (SAS Institute Inc., Cary, N.C.). Descriptive statistics of meteorological information were generated with Excel Graph Wizard (Microsoft, Redmond, Wash.).

\section{Results and Discussion}

Flower bud development among the cultivars investigated in this study proceeded similarly to the descriptions of bud differen-

Fig. 1. Photomicrographs showing floral bud development in blackberry. (a) Development of inflorescence axis with the terminal floral bud at the early stage (Stage 4) of differentiation and showing production of leaf (Lf) primordia. A whorl of sepal primordia (S) is alternating with petal primordia (small arrow). Inception of central receptacle ( $\mathrm{R})$ enlarging to form a torus. Note acropetal differentiation of subtending flowers. Numbers indicate order of maturation. Bar $=0.2 \mathrm{~mm}$. (b) Development of inflorescence axis at more advanced stage of differentiation. Sepal and petal primordia have been excised. The enlarged central receptacle of the terminal floral bud (T) is now at stage 9. Note that there are numerous carpel primordia already formed on the torus. Stamen primordia are evident (small arrows) on "floral cup". Subtending floral buds (1 and 2) are smaller and less advanced as indicated by fewer carpel primordia in the central receptacle. Acropetal differentiation among lateral floral primordia (large arrows) is evident. Numbers indicate order of maturation. Bar $=0.5 \mathrm{~mm}$.

hedge. Lateral branch length thus varied from $\approx 0.5$ to $1 \mathrm{~m}$. Buds were collected from lateral branches located at 0.5 to $1 \mathrm{~m}$ high on the canes. All the types of blackberries sampled in Oregon were grown according to standard commercial practice (Crandall, 1995). Plants received annual fertilizer applications of $\mathrm{N}-\mathrm{P}-\mathrm{K}$ $\left(45,19.6\right.$, and $37.4 \mathrm{~kg} \cdot \mathrm{ha}^{-1}$, respectively) in April and additional $\mathrm{N}-\mathrm{P}-\mathrm{K}\left(25,10.9\right.$, and $20.8 \mathrm{~kg} \cdot \mathrm{ha}^{-1}$, respectively), in late May. Supplemental overhead irrigation was provided weekly at a rate of $3 \mathrm{~cm}$ as needed from June to September.

In West Virginia, axillary buds were collected from lateral branches of 4-year-old (in 1995) 'Chester Thornless' blackberry plants established at $1.3 \times 4-\mathrm{m}$ spacing on a Hagerstown silt loam soil (fine, mixed, Typic Hapludalf). Plants were trained to a rotating cross-arm (RCA) trellis (Takeda and Peterson, 1999) to facilitate machine harvest. Cane training on a RCA trellis involves the bending of the terminal end of primocanes, when they are $\approx 1.1 \mathrm{~m}$ tall, and securing the subsequent growth to a training wire located $0.9 \mathrm{~m}$ above the ground. This forces the primocanes to grow another $1.4 \mathrm{~m}$ to the adjacent plant at which point the shoot is tipped. The purpose of shoot bending and tipping is to increase lateral branch numbers on the primocane. Plot maintenance and plant care followed the published bramble production guidelines for the region (Goulart et al., 1991). Plants received annual fertilizer applications $\left(45,19.6\right.$, and $37.4 \mathrm{~kg} \cdot \mathrm{ha}^{-1}$ of $\mathrm{N}, \mathrm{P}$, and $\mathrm{K}$, respectively) in April and supplemental drip irrigation on an as needed basis in June, July, and August. tiation in blackberries provided by Robertson (1957), Takeda and Wisniewski (1989), and Williams (1959). The pattern of differentiation described below is typical of a terminal flower. Other flowers within the inflorescence also matured in the same pattern. In a vegetative bud (Stage 1), scales and leaf primordia encircled

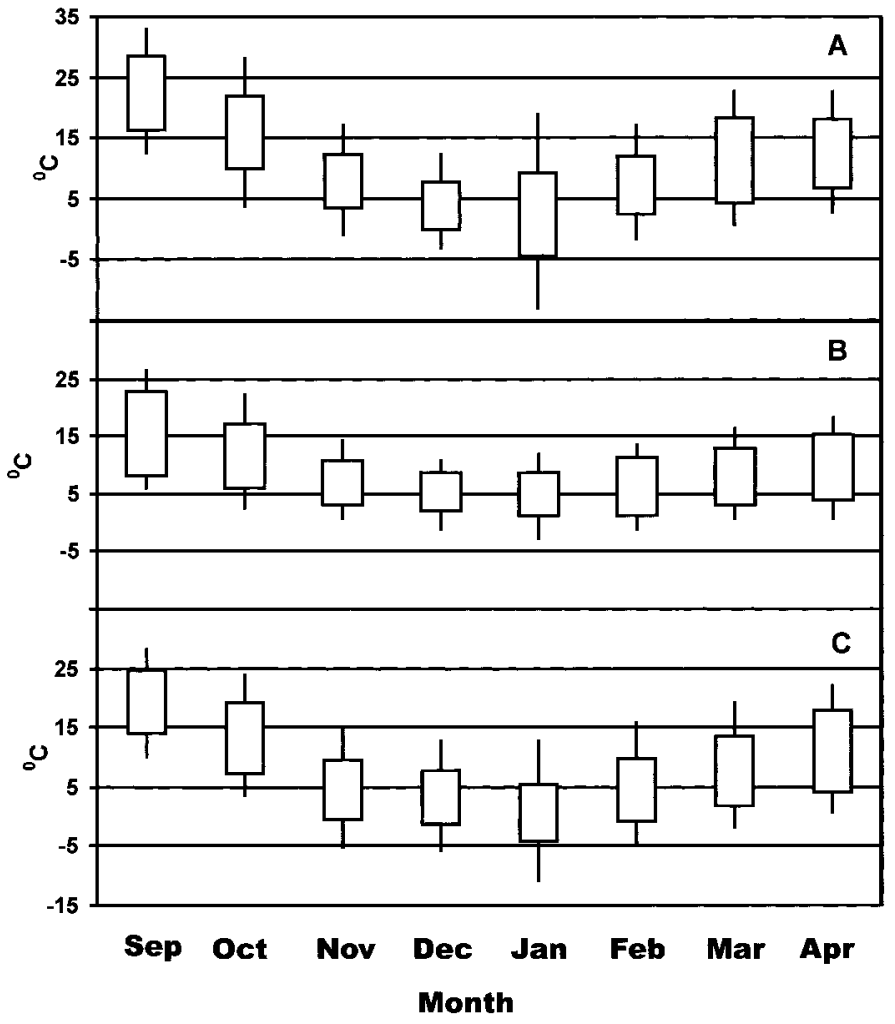

Fig. 2. Box-and-whisker plots showing the seasonality and extent of temperature change for Clarksville, Ark. (A), Aurora, Ore. (B), and Kearneysville, W.Va. (C), from September 1996 to April 1997. Top and bottom sides of the box represent the average maximum and minimum temperatures for the month, respectively. Whiskers at the top and bottom of the box represent one (1) standard deviation, respectively, of the monthly average maximum and minimum temperatures. 
a small apical meristem. As the transition from vegetative to the reproductive phase occurred, the apical meristem greatly enlarged in girth and the development of an inflorescence axis became evident (Fig. 1a). On the elongating axis, additional leaf, transitional phyllome, and bract primordia formed in a helical sequence. Within the axils of bracts on the inflorescence, additional large ovoid floral apices developed.

After the enlargement of the apices, a whorl of usually five sepal primordia arose on the shoulder of the floral apex. As sepal primordia enlarged, a whorl of petal primordia in alternate arrangement with sepals appeared (Fig. 1b), followed by the enlargement and elongation of the central receptacle (torus). Petal primordia developed slowly in contrast to sepals, which became large and eventually enclosed the flower (Fig. 1b). Numerous stamen primordia appeared at the base of the adaxial surface of sepal primordia (floral cup). This was soon or concomitantly followed by the differentiation of carpel primordia on the elongated receptacle. Stamen primordia developed further by differentiation of anther filaments and anther sacs. Carpel development on the torus occurred in an acropetal, helical sequence (Fig 1b). On the carpel primordia, the gynoecial structures developed as the base enlarged to form an ovary and with the appearance of the styles and stigmata. Subsequent development of stamens and carpels appeared to be synchronous so that the structures would mature within each flower at about the same time.

Differentiation of floral buds within a single inflorescence was clearly acropetal (Fig. 1a and b). The subsequent differentiation of buds proceeded acropetally or towards the apical meristem (Fig. 1b). This pattern of flower bud development was similar to the pattern described for anthesis of flowers within an inflorescence (Takeda, 1987).

The monthly average maximum and minimum temperatures from September 1996 to April 1997 for the three sites (Clarksville, Aurora, and Kearneysville) are shown in Fig. 2. The results indicate that the fall, winter, and spring temperatures varied between the three sites. The fall temperatures were highest at Clarksville, and lowest at Aurora. In September, the average maximum and minimum temperatures ranged from 31 and $16^{\circ} \mathrm{C}$ and 23 and $8{ }^{\circ} \mathrm{C}$, in Clarksville and Aurora, respectively. The winter temperatures were highest at Aurora. and lowest at Kearneysville. In midwinter, the average monthly maximum and minimum temperatures ranged from 9 and $1^{\circ} \mathrm{C}$ at Aurora, to only 5 and $-4{ }^{\circ} \mathrm{C}$ at Kearneysville. From late winter to spring, the temperatures increased most rapidly at Clarksville and the least at Aurora. The monthly average maximum, mean, and minimum temperatures for the previous season (September 1995 to April 1996) for the three sites were similar to the 1996-97 temperature data presented in Fig. 2, with the exception of somewhat a longer period of temperatures less than $0{ }^{\circ} \mathrm{C}$ in West Virginia (data not presented).

In this study, there was a considerable difference among blackberry cultivars as to when the axillary buds began to exhibit morphological features that were indicative of a reproductive bud. In Oregon, axillary buds of 'Cherokee', 'Chester Thornless', 'Boysen', and 'Marion' exhibited a broadened apical meristem or stage 3 in October, early February, early November, and late November, respectively (Tables 1, 2, and 3). In 'Cherokee', the buds had already reached stage 4 by October with differentiation of sepal primordia on the broadened apex. There was considerable bud development in all three cultivars (Boysen, Cherokee, and Marion) by December and that continued throughout the winter (Tables 1 and 3). Within the two trailing types, 'Boysen' was at more advanced stages of bud development than 'Marion' from November to February (Table 3). Average daily mean temperatures in Oregon were well above $0{ }^{\circ} \mathrm{C}$ during most of the sampling period (Fig. 1b). In 'Chester Thornless' there was some development of the inflorescence axis in the fall (Table 2). In addition, a few buds examined in winter exhibited an inflorescence axis, suggesting that in Oregon the transition to reproductive development in 'Chester Thornless' may have occurred in late fall because the prevailing temperatures were above $0{ }^{\circ} \mathrm{C}$ well into December. Buds of 'Chester Thornless' continued to develop slowly during the winter months into spring.

In most cultivars bud development and elongation of inflorescence axis progress slowly, or not at all, during winter. Typically multiple layers of tightly formed bud scales and leaf primordia encircle the apical meristem and the internodes between the lateral appendages of the bud axis are compressed until bud emergence in spring. However, the morphology of buds of 'Thornless Evergreen' was unique among the cultivars examined (data not presented). Internodes expanded in autumn and winter such that many axillary buds had become $1.0-\mathrm{cm}$-long spur-like shoots and had developed secondary lateral buds. Such growth response indicated that the mechanism controlling development of primordia and elongation of internodes were not the same. It is likely that the chilling requirement to break bud endodormany was unfulfilled in the case of 'Thornless Evergreen'; however, accumulation of heat units during winter was sufficient to cause resumption of some internode elongation. Studies on raspberries indicated that buds failed to grow properly and formed a rosette when plants were exposed to higher forcing temperatures without adequate chilling temperatures (Takeda, 1993).

Sufficient numbers of 'Thornless Evergreen' buds could not be examined for the stage of flower bud development because the apical meristem was mechanically damaged or tissue had become necrotic. For this reason, 'Thornless Evergreen' blackberry was

Table 1. Development of primary axillary bud in 'Cherokee' blackberry growing in Arkansas and Oregon. Buds on lateral branches were examined from September to April during the 1996-97 and 1997-98 seasons and from August to October in the 2000 season. For detailed description of each developmental stage, refer to Takeda and Wisniewski (1989).

\begin{tabular}{lccccccccc}
\hline \hline & \multicolumn{7}{c}{ Bud developmental stage $^{\mathrm{z}}$} \\
\cline { 2 - 9 } Location & Aug. & Sept. & Oct. & Nov. & Dec. & Jan. & Feb. & Mar. & Apr. \\
\hline Arkansas & $1.0 \mathrm{a}$ & $1.5 \mathrm{a}$ & $4.1 \mathrm{a}$ & $5.0 \mathrm{a}$ & $6.8 \mathrm{a}$ & $6.8 \mathrm{a}$ & $7.0 \mathrm{a}$ & $7.0 \mathrm{a}$ & 8.8 \\
Oregon & $1.0 \mathrm{a}$ & $1.4 \mathrm{a}$ & $4.0 \mathrm{a}$ & $5.3 \mathrm{a}$ & $6.3 \mathrm{a}$ & $8.5 \mathrm{~b}$ & $8.2 \mathrm{~b}$ & $9.3 \mathrm{~b}$ & ND $^{\mathrm{y}}$
\end{tabular}

${ }^{\mathrm{z}}$ Mean separated within columns by LSD, $P \leq 0.05$. Briefly, key descriptors of bud developmental stages are as follows: Stage $1=$ vegetative; Stage $2=$ inflorescence axis; Stage $3=$ broadened apex with sepal primordia; Stage $4=$ three-lobed sepal primordia; Stage $5=$ petal primordia; Stage 6 $=$ dome-shaped receptacle; Stage $7=$ stamen primordia; Stage $8=$ pistil primordia on bottom-half of receptacle; Stage $9=$ pistil primordia cover most of receptacle; and Stage $10=$ anther sacs on stamen and stylar and stigmatic tissues on pistil primordia, respectively.

${ }^{\mathrm{y}} \mathrm{ND}=$ not determined. 
Table 2. Development of primary axillary bud in 'Chester Thornless' blackberry growing in Arkansas, Oregon, and West Virginia. Buds on lateral branches were examined from September to April during the 1996-97 and 1997-98 seasons.

\begin{tabular}{lcccccccc}
\hline \hline & \multicolumn{7}{c}{ Bud developmental stage $^{\mathrm{z}}$} \\
\cline { 2 - 8 } Location & Sept. & Oct. & Nov. & Dec. & Jan. & Feb. & Mar. & Apr \\
\hline Arkansas & ND $^{\mathrm{y}}$ & $1.0 \mathrm{a}$ & $1.0 \mathrm{a}$ & $1.2 \mathrm{a}$ & $1.4 \mathrm{~b}$ & $1.4 \mathrm{~b}$ & $1.4 \mathrm{~b}$ & $7.9 \mathrm{~b}$ \\
Oregon & 1.1 & $1.2 \mathrm{a}$ & $1.3 \mathrm{~b}$ & $1.9 \mathrm{~b}$ & $2.3 \mathrm{c}$ & $2.8 \mathrm{c}$ & $4.8 \mathrm{c}$ & $8.0 \mathrm{~b}$ \\
West Virginia & $\mathrm{ND}$ & $1.0 \mathrm{a}$ & $1.0 \mathrm{a}$ & $1.0 \mathrm{a}$ & $1.0 \mathrm{a}$ & $1.0 \mathrm{a}$ & $1.0 \mathrm{a}$ & $5.0 \mathrm{a}$ \\
\hline
\end{tabular}

${ }^{\mathrm{z}}$ Mean separation within columns by Duncan's multiple range test, $P \leq 0.05$. See Table 1 for key descriptors of bud developmental stages.

${ }^{\mathrm{y}} \mathrm{ND}=$ not determined.

Table 3. Development of primary axillary buds of 'Boysen' and 'Marion' blackberries growing in Oregon. Buds were sampled from the middle onethird section of main canes from October to March during the 1996-97 and 1997-98 seasons.

\begin{tabular}{llllll}
\hline \hline & \multicolumn{5}{c}{ Bud developmental stage $^{\mathrm{z}}$} \\
\cline { 2 - 6 } Cultivar & Oct. & Nov. & Dec. & Jan. & Feb. \\
\hline Boysen & $2.4 \mathrm{a}$ & $5.3 \mathrm{~b}$ & $7.5 \mathrm{~b}$ & $7.5 \mathrm{~b}$ & $8.7 \mathrm{~b}$ \\
Marion & $2.3 \mathrm{a}$ & $3.6 \mathrm{a}$ & $6.1 \mathrm{a}$ & $6.8 \mathrm{a}$ & $9.6 \mathrm{a}$ \\
& & & & $9.7 \mathrm{a}$ & \\
\hline
\end{tabular}

${ }^{\mathrm{z}}$ Mean separation within columns by LSD test, $P \leq 0.05$. See Table 1 for key descriptors of bud developmental stages.

not included in the analysis. It was observed that budbreak and bloom occurred late in 'Thornless Evergreen' compared to other cultivars examined in this study.

In Arkansas, 'Cherokee' buds had differentiated sepals and petals by November (Table 1). However, during the period from December to February when the average daily mean temperatures were near or below $0^{\circ} \mathrm{C}$, little or no bud development occurred in buds of 'Cherokee'. Thus bud development in Arkansas lagged behind that in Oregon during winter and into spring. In March, buds of 'Chester Thornless' from Arkansas had differentiated stamen primordia while buds of 'Cherokee' from Oregon had clearly differentiated all gynoecial structures (Table 1). In contrast, buds of 'Chester Thornless' in Arkansas did not progress beyond stage 2 until April when a rapid development of floral parts occurred with onset of more favorable environmental conditions for growth (Fig. 2 and Table 2).

In West Virginia, average daily mean temperatures were below $5{ }^{\circ} \mathrm{C}$ from November to February (Fig. 2), with daily minimum temperatures dropping below $0^{\circ} \mathrm{C}$ on numerous occasions. Axillary buds of 'Chester Thornless' remained vegetative during the winter months (Table 2). However, once the inflorescence axis was initiated in April, subsequent development was accelerated. Among the thornless blackberry cultivars studied for flower bud development in West Virginia, the time of inflorescence axis initiation was as early as October for 'Black Satin' or as late as April for 'Hull Thornless' (Takeda and Wisniewski, 1989). The time of flower bud development in 'Chester Thornless' was more like that of 'Hull Thornless' than that of 'Black Satin'.

The blackberries with erect or semi-erect growth habit, typical of cultivars (e.g., Cherokee and Chester Thornless) developed by the University of Arkansas and USDA in Beltsville, Md., are summer pruned at 1.5 to $2 \mathrm{~m}$ height and lateral branches are shortened to 30 to $50 \mathrm{~cm}$ (Patterson, 1992; Strik, 1992). In 'Cherokee' and 'Chester Thornless' pruned in this manner, bud number ranged from 10 to 15 buds per lateral branch. Bud development within each of these shortened laterals located at 1.0 to $1.5 \mathrm{~m}$ height was rather uniform and not affected by their position on the branch (data not presented).

The basic mechanisms involved in the regulation of bud endodormancy as well as flower bud induction and differentia- tion in horticultural plant systems are still not clearly understood. The efficacy of various temperatures to satisfy the chilling requirement at different times during endodormancy has been suggested for several deciduous tree crops. There are examples that indicate that the time necessary to meet the chilling requirement for endodormancy release is similar to that necessary to achieve maximum flower induction (Powell, 1987). These interpretations provide only phenological evidence, i.e., flower bud induction and release of dormancy in lateral buds that include the temperature optima and exposure time or chilling requirements for budbreak and shoot growth. Among the blackberry cultivars grown in Oregon, the chilling requirement for removing endodormancy in buds and subsequent shoot extension ranges from as little as $300 \mathrm{~h}$ for 'Marion' to as much as $800 \mathrm{~h}$ for 'Chester Thornless' blackberries (B. Strik, personal communication). Flower initiation in blackberries (e.g., 'Boysen', 'Cherokee', and 'Marion') occurs in early fall which suggests that shorter photoperiods and lower temperatures are necessary for flower initiation. However, in 'Cherokee', floral bud differentiation clearly occurred in absence of low temperatures $\left(<5^{\circ} \mathrm{C}\right)$. It is plausible that the time of flower initiation is related to slowing of growth and cessation of shoot extension towards the end of the season. Cold induction for flowering or vernalization serves as a seasonal timing mechanism that allows perennial plants to fill specific niches (Metzger, 1996). Apparently, in some blackberry cultivars, an exposure to vernalizing temperatures is not necessary for the differentiation of floral organs.

The extent of bud development in 'Chester Thornless' was considerably less than in 'Cherokee', 'Boysen', or 'Marion' blackberries during the same period. 'Chester Thornless' is hardier and has a higher chill requirement (Galletta et al., 1998). The transition to reproductive stage apparently occurs much later in eastern thornless blackberry cultivars. 'Chester Thornless' lagged behind other cultivars examined in our study. Little or no floral organ development was observed in fall or winter at Clarksville and Kearneysville. Development of the inflorescence axis in 'Chester Thornless' occurred in winter at Aurora, where temperatures remained above $0{ }^{\circ} \mathrm{C}$ (Table 2 and Fig. 2) and sepal primordia developed in March, whereas, much of the floral bud development in 'Chester Thornless' growing at Clarksville and Kearneysville occurred in April. The results of this study in which 
'Chester Thornless' was grown at three sites with different winter and spring temperature profiles clearly demonstrate that temperature has a profound effect on the rate of bud development. In April, bud development was most rapid in Arkansas. The rate and degree of floral bud development in spring is probably associated with the accumulation of growing degree hours.

In an environment like Oregon with moderate winter temperatures, the amount of flower bud development that occurs in winter in a given cultivar is likely related to the amount of chilling hours required to remove dormancy. Cultivars such as 'Marion', with its low chilling requirement $(<300 \mathrm{hrs})$ and capacity to develop flower buds continuously in mild winter conditions, may be more suitable for intensive greenhouse production or in mild climates, such as Oregon and New Zealand, since the resumption of spring growth will occur much earlier than those cultivars in which much of flower bud development occurs in spring.

The blackberry has a clearly defined growth cycle (Moore and Skirvin, 1990). In biennial-fruiting cultivars such as the ones investigated here, vegetative growth occurs in the first year (primocane). The vegetative shoots grow vigorously in length and buds develop in the leaf axils. The primocane exhibits strong apical dominance since only a few lateral branches develop from leaf axils. Lateral branching is typically promoted by removal (topping) or bending of shoot terminal (Takeda and Peterson, 1999).

Early in the primocane development, the axillary buds are clearly vegetative as they have potential to develop into lateral branches. However, in late summer or early fall when shoot extension growth is diminished, an irreversible process termed "flower induction" occurs in the axillary buds. The end result is that some parts of the meristem are programmed to form flowers (Wellensiek, 1977). In this study, we have described morphological changes in the apex following the induction which result in the development of the flower primordia and later the distinguishable parts of the complete flowers. Flower bud differentiation is a specific growth program directed by the internal makeup of the plant and modified by environmental and correlative factors (Romberger, 1963; Zeevaart, 1976). Here, we have provided information regarding flower bud differentiation in two cultivars (Cherokee and Chester Thornless) growing in different environments that are not geographically close. The results indicated that both the environment and cultivar affected the onset of reproductive bud development and the rate at which the differentiation of floral organs occurred in buds.

In conclusion, our morphological studies of blackberry cultivars grown under different winter conditions indicate that temperature plays a major role in determining the extent of bud differentiation during winter. In areas such as Oregon where daily mean temperatures usually remained above $4{ }^{\circ} \mathrm{C}$ during winter, bud development in some cultivars that were bred in Oregon and Arkansas, presumably with low chilling requirements, occurred throughout the winter, with an increasing complexity in the floral organs within the bud. During the endodormant period, the internode elongation and expansion of cataphylls and true leaves generally were inhibited but the apical primordia continued to change in morphological complexity. In these cultivars, winter appeared to be a period of interrupted growth. The results of an earlier study suggested that blackberry buds require exposure to temperatures above $2{ }^{\circ} \mathrm{C}$ to bring about tissue deacclimation (Warmund et al., 1992).

Additional phenological and morphological studies are required to better understand the relationship between flower bud development and heat unit accumulation in late summer, fall and winter, and absolute temperature threshold for continuation of flower primordia development during winter that culminates in full extension of fruiting shoot, bloom, and fruit growth in subsequent growing season. Understanding the effects of low temperatures in autumn and winter and rising temperatures in late winter and early spring on bud growth in blackberry should lead to development of chill unit and temperature-growth models which would be useful for predicting dormancy release and for developing harvest prediction models based on accumulated temperatures in late winter and early spring. This information will be useful for growing blackberries at low latitudes, in areas with mild winters, and especially in greenhouse environment because of the need to optimize vegetative and reproductive development for scheduling crop production. Winter temperature has a profound effect on different phases of annual growth cycle of blackberries. In addition to having an effect on flower bud initiation and the rate of differentiation, winter temperature influences the uniformity of budbreak and bloom and the time and duration of fruiting season. The development of methods or the understanding of physiological processes to overcome uneven and poor bud break will lead to more efficient and economical blackberry production.

\section{Literature Cited}

Brierly, W.G. 1948. Preliminary report of an informal cooperative study of rest in the Latham raspberry. Proc. Amer. Soc. Hort. Sci. 51:316318.

Buban, T. and M. Faust. 1982. Flower bud induction in apple trees: Internal control and differentiation, p. 174-203. In: J. Janick (ed.). Horticultural reviews. vol. 4. AVI Publishing Co., Westport, Conn.

Carew, J.G., T. Gillespie, J. White, H. Wainwright, R. Brennan, and N.H. Battey. 2000. The control of the annual growth cycle in raspberry. J. Hort. Sci. Biotechnol. 75:495-503.

Carew, J.G., K. Mahmood, J. Darby, P. Hadley, and N.H. Battey. 2001. The effects of low temperatures on the vegetative and flowering of the primocane fruiting raspberry 'Autumn Bliss'. J. Hort. Sci. Biotechnol. 76:264-270.

Chouard, P. 1960. Vernalization and its relation to dormancy. Annu. Rev. Plant Physiol. 11:191-237.

Crandall, P.C. 1995. Bramble production. The management and marketing of raspberries and blackberries. Food Products Press, Binghamton, N.Y.

Galletta, G.J., A.D. Draper, J.L. Maas, R.M. Skirvin, A.G. Otterbacher, H.J. Swartz, and C.K. Chandler. 1998. 'Chester Thornless' blackberry. Fruit Var. J. 52:118-123.

Goulart, B.L., M. Brittingham, J. Harper, P. Heinemann, W. Hock, E. Rajotte, J. Rytter, and J. Travis. 1991. Small fruit production and pest management guide, 1991-92. Pa. State Univ., College Agr. Sci. AGRS 53.

Hoover, E., J. Luby, D. Bedford, M. Pritts, E. Hanson, A. Dale, and H. Daubeny. 1989. Temperature influence on harvest date and cane development of primocane-fruiting raspberries. Acta Hort. 262:297-303.

Jennings, D.L. 1988. Raspberries and blackberries: Their breeding, diseases and growth. Academic Press, London, U.K.

Lin, J., B. Shabany, and D. Ramos. 1977. Pistillate flower development and fruit growth in English walnut cultivars. J. Amer. Soc. Hort. Sci. 102:702-705.

Metzger, J.D. 1996. A physiological comparison of vernalization and dormancy chilling requirement, p. 147-155. In: G.A. Lang (ed.). Plant dormancy: Physiology, biochemistry and molecular biology. CAB Intl., Wallinford, U.K.

Moore, J.N. and J.D. Caldwell. 1985. Rubus, p. 226-238. In: A.H. Halevy (ed.). CRC handbook of flowering. vol. 4. CRC Press, Boca Raton, Fla. 
Moore, J.N. and R.M. Skirvin. 1990. Blackberry management, p. 214 244. In: G.J. Galletta and D.C. Himelrick (eds.). Small fruit crop management. Prentice Hall Press, Englewood, N.J.

Patterson, W.K. 1992. Blackberry production in Arkansas. Univ. Ark. Coop. Ext. Fact Sheet A2082.

Powell, L.E. 1987. The hormonal control of bud and seed dormancy in woody plants, p. 539-552. In: P.J. Davis (ed.). Plant hormones and their role in plant growth and development. Martinus Nijhoff Publishers, Boston, Mass.

Robertson, M. 1957. Further investigation of flower-bud development in the genus Rubus. J. Hort. Sci. 32:265-273.

Romberger, J.A. 1963. Meristems, growth, and development in woody plants. An analytical review of anatomical, physiological, and morphogenic aspects. USDA Tech. Bul. 1293.

Strik, B. 1992. Blackberry cultivars and production trends in the Pacific Northwest. Fruit Var. J. 46:202-206.

Takeda, F. 1987. Some factors associated with fruit maturity range in cultivars of the semi-erect tetraploid thornless blackberries. HortScience 22:405-408.

Takeda, F. 1993. Chilling affects flowering of primocane-fruiting 'Heritage' red raspberry. Acta Hort. 352:247-252.

Takeda, F., J.C. Crane, and J. Lin. 1979. Pistillate flower bud development in pistachio. J. Amer. Soc. Hort. Sci. 104:229-232.

Takeda, F. and D.L. Peterson. 1999. Considerations for machine harvesting fresh-market eastern thornless blackberries: Trellis designs, cane training systems, and mechanical harvester developments. HortTechnology 9:16-21.
Takeda, F. and M. Wisniewski. 1989. Organogenesis and patterns of floral bud development in two eastern thornless blackberry cultivars. J. Amer. Soc. Hort. Sci. 114:528-531.

Thomas, B. and D. Vince-Prue. 1997. Photoperiodism in plants. 2nd ed. Academic Press, London, U.K.

Tufts, W.P. and E.B. Morrow. 1925. Fruit bud differentiation in deciduous fruits. Hilgardia 1:121-125.

Waldo, G.F. 1933. Fruit bud formation in brambles. Proc. Amer. Soc. Hort. Sci. 30:263-267.

Warmund, M.R. and M.F. George. 1990. Freezing survival and supercooling in primary and secondary buds of Rubus spp. Can. J. Plant Sci. 70:893-904.

Warmund, M.R., M.F. George, and B.G. Cumbie. 1988. Supercooling in 'Darrow' blackberry buds. J. Amer. Soc. Hort. Sci. 113:418-422.

Warmund, M.R., M.F. George, M.R. Ellersieck, and J.V. Slater. 1989. Susceptibility of blackberry tissues to freezing injury after exposure to 16C. J. Amer. Soc. Hort. Sci. 114:795-800.

Warmund, M.R., F. Takeda, and G.A. Davis. 1992. Supercooling and extracellular ice formation in differentiating buds of eastern thornless blackberry. J. Amer. Soc. Hort. Sci. 117:941-945.

Wellensiek, S.J. 1977. Principles of flower formation. Acta Hort. 68:1727.

Williams, I.H. 1959. Effects of environment on Rubus idaeus L.: IV. Flower initiation and development of the inflorescence. J. Hort. Sci. 34:219-228.

Zeevaart, J.A.D. 1976. Physiology of flower formation. Annu. Rev. Plant Physiol. 27:321-348. 